\title{
Problem of measurement of efficiency of propaganda (on the example of using of the index of effectiveness of the russian propaganda in Ukraine)
}

\author{
Oliinyk O. V., Taras Shevchenko National University of Kyiv \\ Lyasota L. I., National Aviation University
}

The article analyzes the possible effects of propaganda and justifies the possibility of empirical evaluation of its effectiveness. There are described main trends in the depending of approving the principal Russian propaganda theses by different categories of the population of Ukraine, based on the results of recent studies of the Kiev International Institute of Sociology and Ukrainian Institite for Social Research named after O. Yaremenko. A critical analysis of measuring the effectiveness of propaganda methodics, identifying areas for further improvement are made.

The article presents the analysis of the experience of Ukrainian sociologists connected with the research of Russian propaganda in Ukraine in the period from 2015 to 2018. The authors focus their attention on the theoretical approaches to the definition of propaganda, effects of propaganda and methodological possibilities of measuring it in empirical research. Relying on the latest statistical data, the authors determine the specificity of effectiveness of Russian propaganda in Ukraine and factors influencing its effectiveness. They also pay attention to the main difficulties of the study of propaganda.

It is done the analysis of possible effects of propaganda, namely the group of general criteria (such criteria also include knowledge, beliefs, actions) and the group of specific criteria (psychological, cognitive, and behavioral effects).

Based on the results of the latest researches of the Kiev International Institute of sociology and the Ukrainian Institite for Social Research named after O. Yaremenko, the authors pointed out the main trends of suportance the main points of Russian propaganda by different categories of the population of Ukraine, including the dependence on the region of residence, national and linguistic identification and level of the respondents' income. It is noted that there is an urgent need to strengthen the system of counteraction to the Russian propaganda (especially from the Ukrainian media, as well as public authorities).

The article raises methodological problem of the possibility of studying the effectiveness of Russian propaganda in principle. Using the results of the discussion of the index of effectiveness of Russian propaganda (RRS), which was developed by the staff of the Kiev International Institute of Sociology in 2015, in the professional community of sociologists, the authors undertook a critical analysis of the methods of measuring the effectiveness of propaganda and the possibility of empirical evaluation of its effectiveness. As a result, it is identified areas for further improvement of the methodology of measuring the effectiveness of propaganda, namely: an increased study of the behavioral effects of propaganda, conducting regular measurements to allow comparisons, the development of comprehensive studies of the manifestations of the results of the propaganda of various methods (including psychological testing, involvement in the experiment several control groups, etc.).

Keywords: sociology of communication; mass media; propaganda; propaganda effectiveness index; propaganda effect

\section{Проблема вимірювання ефективності пропаганди (на прикладі застосування індексу результативності російської пропаганди в Україні)}

\section{Олійник О. В., Київський національний університет імені Тараса Шевченка \\ Лясота Л. І., Національний авіаційний університет}

Стаття присвячена методологічним проблемам вивчення ефективності російської пропаганди в Україні (20152018 р.). ІЇї мета - спираючись на теоретичні підходи визначення пропаганди та спроби емпіричного дослідження ефективності пропаганди, а також на сучасні статистичні дані, визначити специфіку та основні складності дослідження пропаганди, характерні риси результатів російської пропаганди в Україні та чинники, що впливають на її ефективність.

Проведено аналіз можливих ефектів пропаганди, обгрунтовано можливість емпіричної оцінки їі результативності. Спираючись на результати останніх досліджень Київського міжнародного інституту соціології та Державного інституту соціологічних досліджень ім. О. Яременка, авторки окреслили основні тенденції залежності підтримки головних тез російської пропаганди різними категоріями населення України.

Проведено критичний аналіз методики вимірювання ефективності пропаганди, визначено напрямки подальшого її вдосконалення, а саме: посилення вивчення поведінкових ефектів пропаганди, проведення регулярних замірів для забезпечення можливості порівняння, розвиток комплексних досліджень виявів результатів пропаганди різними методами (у т. ч. психологічного тестування, залучення до експерименту кількох контрольних груп тощо).

Ключові слова: соціологія комунікацій; засоби масової інформації; пропаганда; індекс результативності пропаганди; ефект пропаганди 


\title{
Проблема измерения эффективности пропаганды (на примере применения индекса результативности российской пропаганды в Украине)
}

\author{
Олейник О. В., Киевский национальный университет имени Тараса Шевченко \\ Лясота Л. И., Национальный авиационный университет
}

Статья посвящена методологическим проблемам изучения эффективности российской пропаганды в Украине (2015-2018 гг.). Целью даннной статьи является определение специфики и основных проблем исследования пропаганды, характерные признаки результативности российской пропаганды в Украине и факторов, которые влияют на ее эффективность, на основе изучения теоретических подходов определения пропаганды, а также методов эмпирического исследования ее эффективности, современных статистических данных.

В статье осуществлен анализ возможных эфектов пропаганды, обоснована возможность ее эмпирической оценки та результативности. Анализируя результаты последних исследований Киевского международного института социологии и Государственного института социологических исследований им. А. Яременко, авторы охарактеризовали основные тенденции зависимости поддержки основных тезисов российской пропаганды различными категориями населения.

Также был проведен критический анализ измерения эффективности пропаганды, определены основные направления его усовершенствования, а именно: усиление изучения поведенческих эффектов пропаганды, проведения регулярных замеров для возможности сравнительного анализа, развитие комплексных исследований проявлений результатов пропаганды различными методами (в том числе психологического тестирования, задействования в эксперимент нескольких контрольных групп и т. д.)

Ключевые слова: социология коммуникаций; средства массовой информации; пропаганда; индекс результативности пропаганды; эффект пропаганды

Determination of the relevance of the topic and the formulation of a scientific problem in the context of the subject of science.

$\mathrm{M}$ ethodological problems of measurement of impact of propaganda on mass consciousness are not less actual. Though the problem of measurement of efficiency of propaganda has already been actual in sociological polemic [4] for a long time, however, is still not developed a certain universal reasonable technique. It is connected first of all with complexity and a multifactoriality of the process of formation of opinions and judgments of people of some events and processes, in particular - with impossibility to distinguish propaganda influence from otists' factors.

\section{Statement of a scientific problem.}

The latest events in Ukraine, in particular information war, which is waged by Russia against Ukraine couldn't but draw attention of sociologists to questions by studying of propaganda. Already known methods of propaganda, effects of propaganda, a technique of the opposition of the identity of its influence are actively investigated and compared in scientific publications and also in the media. No smaller interest raises questions of measurement and assessment of efficiency of its influence on the opinions of people and consequently, and problems of validity of such techniques.

Aim of the article is relying on theoretical approaches of the definition and attempt of an empirical research of efficiency of propaganda and also modern statistical data, to define specifics and the main difficulties of the research of propaganda, characteristic features of the results of the Russian propaganda in Ukraine and the factors influencing its efficiency.

\section{Analysis of recent publications.}

In modern scientific, sociological literature have acquired relevance, such directions of a research as mechanisms of formation of opinions [1], factors of dissemination of information on social networks [2], information culture and opposition to propaganda [3].

Thus, recent studies carried out by the Kiev International Institute of Sociology and UISD named after O. Yaremenko testify that «the success of antiUkrainian propaganda is quite serious, since both hard («the civil war») and soft («politicians try to quarrel the fraternal people» and «the struggle of other countries for spheres of influence») anti-state thesis maintains 58.7 per cent of the population.» [10, p. 70$], \ll 52 \%$ are of the opinion that the war started by Russia and the separatists» $[9$, p. 8] . At the same time, the effectiveness of counteracting Russian propaganda should be evaluated with cautionaccording to the survey of Kyiv International Institute of sociology «the population of Ukraine is rather critical of perceived effectiveness of both the state and public organizations in countering Kremlin propaganda. Relatively better Ukrainian content is relatively well estimated - in the case of the state, $24 \%$ consider the state to be sufficient in this direction ( $47 \%$ of respondents consider it to be unsufficient), in the case of public organisations, $19 \%$ (against 44\% who consider it insufficient)» [9, p. 9]

Relying on theoretical approaches of the definition and attempt of an empirical research of efficiency of propaganda and also modern statistical data, to define specifics and the main difficulties of the research of propaganda, characteristic features of the results of the Russian propaganda in Ukraine and the factors 
influencing its efficiency.

Presentation of the main results.

The researcitss agree in opinion that effective propaganda can be considered when results of propaganda activities are felt in a change of consciousness, behavior of social groups, certain people, a way of their thoughts.

The understanding of the essence of efficiency of propaganda, surely assumes unambiguous interpretation of its criteria or distinctive signs by which it is possible to judge the results of increase in level of knowledge and education of people. Reflecting achievements of propaganda, its criteria are characterized by many quantitative and qualitative properties. Various criteria of efficiency of propaganda are in own way important. One of them can't be absolutized, opposed to the others or to underestimate as both spiritual, and practical results of propaganda are indissolubly interconnected.

There is a number of criteria of efficiency of propaganda. They have probably empirical, than a theoretical basis and are divided into the general and specific. The difference between them is rather relative and is carried out mainly for formalization of a technique of their practical application. The criteria of knowledge, belief, action belong to the group of the general criteria. The criterion of knowledge defines a degree (level) of awareness, knowledge of people about these or those facts of objective reality. At the same time true knowing of the facts is estimated on as far as the person is capable to connect single with the general, that is adequate to interpret the facts. Despite the external simplicity, criterion of knowledge has rather branched structure into which enter, in particular the following aspects: gnoseological (technical and economic knowledge, ideas, theories, etc.) knowledge of the principles (truthfulness, connection with life, theoretical approach, etc.); systemacity of the acquired knowledge. The criterion of belief is considered exclusively difficult because the concept of belief contains a variety of spiritual powers, thoughts and feelings, mind and even temperament of the personality. The belief is controlled by all psychological phenomena, desires, interests, aspirations, orientation installations. They make organic unity of results of rational cognition of objective reality and the attitude towards its. The criterion of belief can be characterized on several indicators: according to contents (character, a variety and depth of the acquired knowledge, the acquired ideas) on personal to assessment of the gained knowledge and the phenomena which reflection they are; on degree of confidence in the correctness of perception of the ideas, views; according to the consistency of views with real behaviour of the person; behind its readiness for actions in compliance to knowledge and beliefs.

At last, the criterion of action synthesizes criterion of efficiency and defines change in public activity of the personality, in the nature of behaviour, in the morality of the person.

In group of specific criteria of efficiency refer criteria of psychological, informational and behavioural influence. The criterion of psychological influence estimates change of a state and mood of an object of propaganda (audience) in the necessary direction, change of installations (motives), development of cognitive interest. The criterion of informative influence reveals through transitions from ignorance to knowledge, from incomplete knowledge to fuller and exact, from smaller generalization to bigger. The behavioural criterion serves as a logical continuation to previous and is determined by the compliance of acts of people by character of information obtained from propaganda.

Each criterion is divided into the indicators reflecting these or those parts of efficiency. The overall effectiveness in this case acts as the sum of applications of this or that criterion, disclose its content. And the fuller crushing of each criterion on the corresponding indicators is, that is more than opportunities for objective assessment of results of propaganda. To some extent the choice of indicators for various criteria what overall effectiveness can be considered as the sum of separate effects (effect - wider concept, assuming any result of propaganda activity which can confirm (or deny) overall effectiveness). People distinguish several groups of such effects, in particular: cognitive effects, valuable effects, organizational effects, communicative effects.

Cognitive effects are expressed in an increase in volume of knowledge in conscious and unconscious forms, strengthening of an impulse to active reflections, in need of work with the obtained information, check of its objectivity, its judgment, comparable to already available knowledge, desire of dissemination of the obtained information or creation new on the basis of the gained knowledge.

Valuable effects are shown in generation of a new position, (thought, interest...) or in strengthening / weakening of the available position, strengthening of the beliefs or viewing of the point of view, etc. There can be an impulse to the actions connected with the expression of the relation to these or those positions, support, denial and etc.

Not only the impulse to action caused by consumption of information, but also practical actions respectively (or in a contradiction) with the recommendations which are contained in the distributed information belong to organizational effects.

Communicative effects are shown in the distribution, relaying and discussion of the accepted information in the course of interpersonal communication, in reaction to information in the 
feedback mode with the information source.

The given criteria of efficiency can be added and are the basis for a uniform technique of determination of overall effectiveness of propaganda.

Studying and the constant analysis of separate effects, their assessment by means of the general and specific criteria and definition on this basis of overall effectiveness of separate forms and methods and also propaganda whole are absolutely necessary. They are able to afford to react flexibly to change of public opinion, to be realistic about effectiveness, quality and orientation of these or those propaganda actions. Time intervals of determination of efficiency in general shouldn't be too big, and, depending on activity of propaganda, have to correspond to the moments «throwing» of new information.

One of the attempts of determination of efficiency of propaganda the staff of laboratory sociological has carried out the assistance of information security of the Kiev International Institute of Sociology [5].

The idea of creation of the Index of the effectiveness of the Russian propaganda (ERP) is connected with the need for effective counter-propaganda as decrease in effectiveness of the Russian propaganda on unit of the spent resources for which assessment the indicator of effectiveness of the Russian propaganda is necessary.

The index of effectiveness of the Russian propaganda which has been offered by the Kiev international institute of sociology can become such tool for counter-propaganda activities assessment Ukraine in these or those regions and among these or those social groups.

The effectiveness of the Russian propaganda in the territory of Ukraine is understood as prevalence of support of the main theses of the Russian propaganda by the population of Ukraine in general or this or that territory of Ukraine.

The idea is in choosing such theses of official propaganda in which more than $80 \%$ of the Russian population, that is those theses which have shown the efficiency in Russia and in the occupied territory.

According to developers of an indicator, a kernel of propaganda is quasilogical chain: the area has been organized by Americans together with nationalists $\rightarrow$ owing to the area nationalists who threaten the Russian-speaking population of Ukraine $\rightarrow$ the Crimea and the East of Ukraine were in danger $\rightarrow$ the Crimea managed to be protected, having included it in structure of Russia, and the East has risen and wants independence and security guarantees $\rightarrow$ nationalists, have illegally come to the power, have begun war with the people.

Therefore the judgments covering basic provisions of its quasilogical chains -judgment of the Maidan, assessment of the USA, support of annexation of the Crimea, ATO condemnation, trust to the Russian media, mistrust to the Ukrainian media have been formulated.

Results. The average value of the ERP index of the population of Ukraine in general, it is equal 26 (from 100 possible), dynamics can't be defined as this first measurement.

There are no essential distinctions of gender and age: women $(\mathrm{ERP}=28)$ are more subject to influence of the Russian propaganda, than the men (ERP = 25), but this distinction isn't statistically significant. People are more senior than 70 years $(E R P=29)$ are slightly more subject to influence than on average in Ukraine $(\mathrm{ERP}=26)$.

Education here has also no significant effect faces with the higher education $(E R P=24)$ aren't less subject to propaganda influence, than on average in Ukraine.

The most essential differences in pliability to the Russian propaganda connected with the region of residence of respondents, which lowest level in the Western region (the ERP index $=12$ ) and in the Central region $(E R P=19)$, are higher value of the index in the Southern region (ERP = 32). In Eastern region the value of the index is 4 times higher, than in Western $(E R P=48)$. We see that East region is a big problem and demands serious efforts in the fight against the Russian propaganda. Not a really good situation is in the Southern region.

It is interesting that a certain dependence of values of the index of prosperity level is observed: it has the greatest value among the poor population $(\mathrm{ERP}=38)$, gradually decreases among more wealthy respondents, reaches the lowest value among the richest $(\mathrm{ERP}=3)$.

Also the dependence of IER values on language of communication and national self-identification of respondents is traced: the IER high values the lowest are recorded in Russian-speaking respondents (ERP $=$ 38 ) and those who consider themselves «exclusively Russian» $($ ERP $=66),-$ in Ukrainian-speaking (ERP $=15$ ) and those who identify themselves «exclusively Ukrainian» $(\mathrm{ERP}=20)$.

Some remarks to the creation of the index. From explanations of the authors, not absolutely clear, how exactly occurred measurements and stated comparisons; accurately limits of a variety of values of the index (it is visible by data that it changes from 0 to 100 , but justification isn't given) aren't specified that complicates assessment of its values; the lack of measurements «before» influence of the Russian propaganda and compared with the received values «after» breaks purity of the experiment in some way.

The received results show sufficient sensitivity of the index for intergroup comparisons, and allow to describe certain tendencies of display of the Russian propaganda in thoughts of the population of Ukraine.

It was also a very interesting opinion of sociologists (including Russian) concerning a possibility of carrying out similar measurements 
and assessment of efficiency of propaganda as such [12]. The analysis of a tape of comments professional sociological community in providing the index has allowed to mark out such difficulties, remarks and recommendations to improvement of a technique of determination of efficiency of propaganda:

1) need of cyclic measurements, need to carry out measurements in several control groups, to do it by various methods within the complex research;

2) the main problem - separation of impact of propaganda from «an independent thought» of respondents, complexity to separate propaganda (and its influence) from other factors which form an opinion of people;

3) not the efficiency of propaganda, but prevalence of support of the pro-Russian theses are measured, «the pro-Russian moods» are identified with «the Russian propaganda»;

4) need to compare the opinions of respondents with media channels to which they give preference;

5 ) it is necessary to consider the level of criticality of perception of external information;

6) need for additional testing of respondents for the purpose of clarification of degree of independence of their judgments;

7) change of habitual behaviour - one of results of impact of propaganda which is possible and it needs to be investigated.

From the point of view of assessment of prospects of pro-Ukrainian propaganda and need of counteraction to the Russian propaganda experts have come to unfavorable conclusions [8]:

1) actually there is no system of counteraction to the Russian propaganda in Ukraine, its influence is underestimated;

2 ) information policy actually is absent, the policy of the bans instead of policy of incentives (attempt to enter censorship and to limit the use of the Russian websites) of essential results doesn't yield.

Recommendations to the Ukrainian mass media and also public authorities, the created media initiatives of the public are elaborated. However the researches conducted in November-December, 2017 show that essential changes in perception of a situation of the conflict in the East haven't happened $[6,7,11,13]$ :

1) The number of citizens who scoop information on the state of affairs in the country from relatives, neighbours, acquaintances has almost doubled: in 2015 such were $24 \%$, in 2017 - already $47,7 \%$. When we speak about information about the war in the East, people also began to trust less Ukrainian TV channels as a source of information on these events $(2015-50 \%, 2017-40,4 \%)$ though they also remain the leader, but began to trust more relatives, friends, neighbours $(2015-15 \%, 2017-18,8 \%)$ slightly more.

2) Before that the level of credibility continues to decrease - both to the media, and to the power, and to any of official institutions. Tolerance level with representatives of the other nationalities has also decreased $-62 \%$ have answered that they don't trust (absolutely and mainly) to representatives of the other nationalities.

3) It is quite possible that because of restriction of access to the Russian channels in a cable, the number of those who accept these channels via the satellite has increased $(2015-42 \%, 2017-78,7 \%)$. It once again confirms that only by the bans it is impossible to achieve the steady effect. It is necessary to compete qualitative content. The Ukrainian information product is necessary (including in Russian) which will be so attractive and informative, won't arise need to look for opportunities to accept the Russian TV channels.

4) Contradictory figures in answers of respondents confirm a thesis about not coordination of the work of the Ukrainian media: so, for example, $9 \%$ of respondents are at the same time ready to support also a thesis that in 2014 there was a military takeover, and a thesis about national revolution. $22,3 \%$ of respondents have at the same time supported a thesis about responsibility for failure of the Minsk process and Russia, and Ukraine. $44,8 \%$ of respondents have at the same time supported messages that war continues through interest Ukrainian the government and oligarchs and therefore that Russia doesn't withdraw troops from Donbas and supports LNR and DNR. So, the same respondents agree with mutually exclusive statements.

Of course, this research doesn't answer a question: WHY citizens think in such a way. But it is a certain starting point - and for correction of mistakes (and media, and the authorities and the public sector), and for the other researches.

Conclusions and perspectives of further exploration in the direction of the topic of the article.

Application of the index of the effectiveness of the Russian propaganda in Ukraine has allowed to reveal the following characteristic features as dependence on the region of residence, nationality and language identification, level of prosperity of respondents. The critical analysis of the method itself and its discussion by colleagues has designated such further directions of its improvement: strengthening of studying of behavioural effects of propaganda, carrying out regular measurements for a possibility of comparison, the development of complex researches of manifestations of results of propaganda by various methods (including psychological testing, implication to the experiment of several control groups, etc.). 


\section{БІБІЛІОГРАФІЧНІ ПОСИЛАННЯ}

1. Безверха Г. І. Інформаційна культура як ступінь досконалості людини в умовах становлення інформаційного суспільства // Соціологія, політологія, наук. журн. НАУ. - 2014. - № 2. - С. 4-8.

2. Братчикова Т. І. Фактори поширення інформації в соціальних онлайн мережах: експертне опитування // Вісник Львівського університету. Серія соціологічна. - Львів: ЛНУ імені Івана Франка, 2014. - № 8. - С. 169-179.

3. Грушин Б. А. Эффективность массовой информации и пропаганды: понятие и проблемы измерения. - М., 1979. $-390 \mathrm{c}$.

4. Давыдов С. Пропозиція обговорити Індекс результативності російської пропаганди - результати дослідження лабораторії соціологічного сприяння інфор $\neg$ маційної безпеки КМІС / С. Давыдов // Мануфактура «СОЦПОХ». Режим доступу: https://www.facebook.com/groups/socpokh/perma ᄀlink/843786649027102/

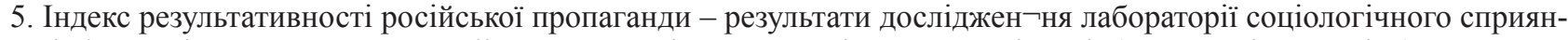
ня інформаційної безпеки КМІС // Київський міжнародний інститут соціології (Прес-релізи та звіти). - Ре $ж и м ~$ доступу: http://www.kiis.com.ua/?lang=ukr\&cat=reports\&id=510\&t $\neg=3 \&$ page $=1$

6. Основні засади та шляхи формування спільної ідентичності громадян України. Інформаційно-аналітичні матеріали до Круглого столу 12 квітня 2017 р. - к., 2017. - 94 с.

7. Оцінка ситуації в країні / Громадяни України // Соціологічні дослідження. - Офіційний сайт Центру Разумкова. - Режим доступу : http://old.razumkov.org.ua/ukr/socpolls.php?cat_id=27

8. Протидія російській інформаційній агресії: спільні зусилля задля захисту демократії. Аналітичний звіт. - Київ: Телекритика, 2015. - 77c.

9. Протидія російській пропаганді та медіаграмотність: результати всеукраїнського опитування громадської думки. Аналітичний звіт // ГО «Детектор медіа». - Режим доступу: http://detector.media/doc/images/news/ archive/2016/136017/AReport_Massmedia_Feb2018_v2.pdf

10. Результати експертно-аналітичного дослідження щодо формування стандартів національно-патріотичного виховання та визначення індикаторів ефективності проведення заходів щодо національно-патріотичного виховання // Міністерство молоді та спорту України. - Режим доступу: dsmsu.gov.ua/media/2018/03/22/18/REZYLTATI_ DRYK_ed.pdf

11. Російсько-український конфлікт очима громадян (Результати загальнонаціонального соціологічного дослідження) // Національна безпека і оборона. - 2016. - № 9-10. - С. 45-53. Режим доступу: http://razumkov.org.ua/ uploads/journal/ukr/NSD167-168_2016_ukr.pdf

12. Хуткий Д. А. Причины формирования мнений населения Украины о региональных геополитических союзах // Вісник Одеського національного універлситету. Серія: Соціологія і політичні науки. - Т. 19. - № 2. - 2014. C. 9-19.

13. Як російська пропаганда впливає на суспільну думку в Україні. Результати опитування, проведеного Київським міжнародним інститутом соціології на замовлення ГО «Детектор медіа». 13 лютого 2017р. - Режим доступу: http://osvita.mediasapiens.ua/mediaprosvita/research/yak_rosiyska_propaganda_vplivae_na_suspilnu_dumku_v_ ukraini_doslidzhennya/

\section{REFERENCES}

1. Bezverha, G. (2014) Informacijna kul'tura jak stupin' doskonalosti ljudini v umovah stanovlennja informacijnogo suspil'stva. Sociologija, politologija, nauk. Zhu NAU, 2, 4-8 [in Ukrainian].

2. Bratchikova, T. (2014) Faktori poshirennja informaciï v social'nih onlajn merezhah: ekspertne opituvannja. Visnik L'vivs 'kogo universitetu. Sociologija. Lviv: LNU imeni Ivana Franka, 8, 169-179 [in Ukrainian].

3. Grushin, B. (1979) Jeffektivnost'massovoj informacii i propagandy: ponjatie i problemy izmerenija [The effectiveness of mass information and propaganda: the concept and problems of measurement]. Moscow [in Russian].

4. Davydov, S. Propozicija obgovoriti Indeks rezul'tativnosti rosijs'koï propagandi - rezul'tati doslidzhennja laboratoriï sociologichnogo sprijannja informacijnoï bezpeki KMIS [The proposal to discuss the Russian propaganda index - the results of the research of the KIIS information safety lab sociological assistance laboratory]. Manufaktura SOCPOH. Retrieved from: https:/www.facebook.com/groups/socpokh/permalink/843786649027102 [in Ukrainian].

5. Indeks rezul'tativnosti rosijs'koi propagandi - rezul'tati doslidzhennja laboratoriï sociologichnogo sprijannja informacijnoï bezpeki KMIS [The index of the effectiveness of Russian propaganda - the results of the research of the KIIS Information Safety Information Society Laboratory]. Kiivs'kij mizhnarodnij institut sociologii (Pres-relizi ta zviti). Retrieved from: http://www.kiis.com.ua/?lang=ukr\&cat=reports\&id=510\&t=3\&page=1 [in Ukrainian].

6. Osnovni zasadi ta shljahi formuvannja spil'noï identichnosti gromadjan Ukraini [Basic principles and ways of formation of the common identity of Ukrainian citizens]. (2017). Informacijno-analitichni materiali do Kruglogo stolu [in Ukrainian].

7. Ocinka situacii v kraini. Gromadjani Ukraini. [Assessment of the situation in the country. Citizens of Ukraine] Sociologichni doslidzhennja. Oficijnij sajt Centru Razumkova. Retrieved from: http://old.razumkov.org.ua/ukr/socpolls. php?cat_id=27 [in Ukrainian].

8. Protidija rosijs'kij informacijnij agresii: spil'ni zusillja zadlja zahistu demokratii. Analitichnij zvit [Opposition to 
Russian information aggression: joint efforts to protect democracy. Analytical report]. (2015). Kyiv: Telekritika [in Ukrainian].

9. Protidija rosijs'kij propagandi ta mediagramotnist': rezul'tati vseukrains'kogo opituvannja gromads'koi dumki. Analitichnij zvit [Opposition to Russian propaganda and media literacy: the results of an all-Ukrainian public opinion poll. Analytical report]. GO «Detektor media». Retrieved from: http://detector.media/doc/images/news/archive/2016/136017/ AReport_Massmedia_Feb2018_v2.pdf [in Ukrainian].

10. Rezul'tati ekspertno-analitichnogo doslidzhennja shhodo formuvannja standartiv nacional'no-patriotichnogo vihovannja ta viznachennja indikatoriv efektivnosti provedennja zahodiv shhodo nacional'no-patriotichnogo vihovannja [Results of expert-analytical research on formation of standards of national patriotic education and determination of indicators of effectiveness of carrying out measures on national patriotic education]. Ministerstvo molodi ta sportu Ukraini. Retrieved from: dsmsu.gov.ua/media/2018/03/22/18/REZYLTATI_DRYK_ed.pdf [in Ukrainian].

11. Rosijs'ko-ukrains'kij konflikt ochima gromadjan (Rezul'tati zagal'nonacional'nogo sociologichnogo doslidzhennja) [Russian-Ukrainian conflict through the eyes of citizens (Results of a nationwide sociological survey)]. (2016) Nacional'na bezpeka i oborona, 9-10, 45-53. Retrieved from: http://razumkov.org.ua/uploads/journal/ukr/NSD167-168_2016_ukr.pdf [in Ukrainian].

12. Hutkij, D. (2014) Prichiny formirovanija mnenij naselenija Ukrainy o regional'nyh geopoliticheskih sojuzah [The reasons for forming opinions of the population of Ukraine on regional geopolitical unions]. Visnik Odes'kogo nacional'nogo universitetu. Sociologija i politichni nauki, 19 (2), 9-19 [in Russian].

13. 13. Jak rosijs'ka propaganda vplivae na suspil'nu dumku v Ukraini (13 ljutogo 2017) [How Russian propaganda affects public opinion in Ukraine]. Rezul'tati opituvannja, provedenogo Kiivs 'kim mizhnarodnim institutom sociologii na zamovlennja GO «Detektor media». Retrieved from: http://osvita.mediasapiens.ua/mediaprosvita/research/yak_rosiyska_ propaganda_vplivae_na_suspilnu_dumku_v_ukraini_doslidzhennya/[in Ukrainian].

\section{Олійник Оксана Валеріївна}

Кандидат соціологічних наук, доцент

Київський національний університет імені Тараса

Шевченка

01033, м. Київ, вул. Володимирська, 60

\author{
Лясота Людмила Іванівна
}

Кандидат політичних наук, доцент

Національний авіаційний університет

02000, м. Київ, проспект Космонавта Комарова, 1

\section{Oliinyk Oksana V.}

Candidate of Sociological Sciences, Associate professor

Taras Shevchenko Kyiv National University

60, Volodymyrska Str., 01033, Kyiv, Ukraine

\section{Lyasota Lyudmyla I.}

Candidate of Political Sciences, Associate professor National Aviation University

1, Kosmonavta Komarova Ave., 02000, Kyiv, Ukraine

Email: o_oliinyk@ukr.net

Email:1.lyasota2007@gmail.com

Цитування: Олійник О. В. Проблема вимірювання ефективності пропаганди (на прикладі застосування індексу результативності російської пропаганди в Україні) / О. В. Олійник, Л. І. Лясота // Науково-теоретичний альманах «Грані». - 2018. - Т. 21. - № 4. - С. 40-46.

Citation: Oliinyk, O.V., \& Lyasota, L.I. (2018). Problema vymiriuvannia efektyvnosti propahandy (na prykladi zastosuvannia indeksu rezultatyvnosti rosiiskoi propahandy v Ukraini) [Problem of measurement of efficiency of propaganda (on the example of using of the index of effectiveness of the russian propaganda in Ukraine)]. Scientific and theoretical almanac «Grani», 21(4), 40-46. 